\title{
AGREEMENT BETWEEN A TEST BASED ON A QUALITATIVE ANALYSIS OF FILMED ACTIONS AND ONE BASED ON A QUESTIONNAIRE FOR ASSESSING STUDENT BODY POSTURE
}

\author{
Arthur Antoniolli \\ Universidade Federal do Rio Grande do Sul, Rio Grande do Sul, Porto Alegre, Brasil \\ Matias Noll \\ Universidade Federal do Rio Grande do Sul, Rio Grande do Sul, Porto Alegre, Brasil \\ Mateus Kunzler \\ Universidade Federal do Rio Grande do Sul, Rio Grande do Sul, Porto Alegre, Brasil \\ Cláudia Tarragô Candotti \\ Universidade Federal do Rio Grande do Sul, Rio Grande do Sul, Porto Alegre, Brasil
}

\begin{abstract}
This article aims to verify if the instruments Back Pain and Body Posture Evaluation Instrument (BackPEI) and Layout for Assessing Dynamic Posture (LADy), which evaluate the dynamic posture of schoolchildren using questionnaires and qualitative analysis of filming, respectively, provide similar concordance on activities, such as sitting down to write, sitting down to use the computer, picking up an object from the ground, and carrying a backpack. The sample was composed by 58 schoolchildren of both sexes (age $=12.94 \pm 1.22$ years, body mass $=52.34 \pm 12.24$ kilograms, and height $=1.64 \pm$ 0.07 meters). The children were evaluated using both instruments. The instruments show similar levels of concordance $(84.5 \%$ to $98.3 \%)$ and significant association $(\mathrm{p}<0.05)$ in the daily activities studied.
\end{abstract}

Keywords: Posture. Students. Qualitative postural evaluation. Concordance.

\section{Introduction}

Studies assessing the prevalence of postural changes in students from Brazil show concerning results, as in the studies developed by Noll et al. (2012a), in which $100 \%$ of the students assessed presented with postural deviations on the sagittal plane, and by Detsch et al. (2007), in which the prevalence of postural changes was $66 \%$ on the sagittal plane and $70 \%$ on the frontal plane. Concerning data related to spine health in students are also shown by studies performed in other countries, such as Spain, where Martínez-Crespo et al. (2009) found $66 \%$ of teenagers with back pain,and England, where Watson et al. (2002) revealed that $24 \%$ of students between 11 and 14 years old had back pain during the month prior to the research, among others (SHEHAB\& JARALLAH, 2005; SKOFFER, 2007; PAANANEN et al., 2010). In general, these studies associate postural problems during childhood and youth with inappropriate postural habits when executing daily life activities (DLAs), such as using heavy backpacks and carrying them inappropriately (KELLIS\& EMMANOUILIDOU, 2010), remaining in an inadequate posture for a long time when seated (SIIVOLA et al., 2004), and 
adopting postures that do not preserve the physiological curvatures of the spine (WOMERSLEY\& MAY, 2006; TREVELYAN\& LEGG, 2006).

Postural habits refer to mechanical body usage during activities performed in daily life; an appropriate postural habit is considered to be one that preserves the physiological curvatures of the spine without exceeding the individual's physiological limit (NOLL et al., 2013b). Otherwise, the postural habit is considered to be inadequate.

Most spine pathologies, which affect a good portion of the population, originate from the school period, when the body structure is still developing (PENHA et al., 2008; SMITH, O'SULLIVAN\& STRAKER, 2008). Therefore, it is essential to investigate and assess the daily habits related to the students' body posture, not only to reflect about the planning of physical education classes and school classes as a whole (NOLL, CANDOTTI\& VIEIRA, 2012; NOLL et al., 2012b), but also to have an early diagnosis that helps carry out this planning. This type of information may guide interventions for re-educating postural habits and, in the long term, contribute to adults having an adequate postural standard (CARDON, CLERCQ\& BOURDEAUDHUIJ, 2000; MÉNDEZ\& GÓMEZ-CONESA, 2001), thus reducing the chances of them developing postural problems.

Regarding the assessment of body posture in students' DLAs, a large part of the studies have used the questionnaire as an instrument to collect data (WATSON et al., 2002; MEHTA, THORPE\& FREBURGER, 2002; BEJIA et al., 2006; SKOFFER, 2007; SCHLADEMANN, MEYER\& RASPE, 2008; KELLIS, EMMANOUILIDOU, 2010; NOLL et al., 2012b), and very few have assessed moving body posture, that is, by filming the students (SPENCE, JENSEN\& SHEPARD, 1984; ROBERTSON\& LEE, 1990; CARDON, CLERCQ\& BOURDEAUGHUIJ, 2000; MÉNDEZ\& GÓMEZ-CONESA, 2001). The great advantage of questionnaire assessment is its easy application and low cost. The greatest advantage of dynamic assessment through filming is the fact that it assesses the execution of the movement; the questionnaire depends on the perception of the respondent him or herself. Authors such as Spence, Jensen, and Shepard (1984); Andreotti and Okuma (1999); and Candotti et al. (2011) have recommended the combined use of both assessment methods, which, in fact, would elevate the quality of the assessment.

However, despite this recommendation, most studies (BEJIA et al., 2006; SKOFFER, 2007; SCHLADEMANN, MEYER\& RASPE, 2008; KELLIS\& EMMANOUILIDOU, 2010) assessing postural habits have used only one assessment instrument and have been restricted to the discussion of their positive and negative points. Considering this perspective and believing that, regardless of the assessment instrument used for researching postural habits, the results should be similar, there was a need to perform a study assessing body posture through the questionnaire, Back Pain and Body Posture Evaluation Instrument (BackPEI) (NOLL et al., 2013a), and by filming and observing dynamic posture using theLay-out for Assessing Dynamic Posture (LADy) (NOLL et al, 2012; NOLL et al., 2013c) to later check if the results provided by the instruments are consistent with one another.

As such, the objective of this study was to check if there is consistency between the results of two instruments for assessing body posture in DLAs, theBackPEI and LADy, in students between 11 and 15 years old for the following DLAs: sitting to write, sitting to use the computer, picking up an object off the floor, and carrying a backpack. 


\section{Materials and Methods}

The study sample comprised 58 students, 34 boys and 24 girls, with a mean age of $12.94 \pm 1.22$ years, body mass of $52.34 \pm 12.24$ kilos, and a height of $1.64 \pm 0.07$ meters, who participated in every step of the study. The inclusion criteria are as follows: (a) regularly attending elementary school, (b) being 11 to 15 years old, and (c) being able to perform the assessment of LADy tasks and understand BackPEI questions. The exclusion criterion was absence from any assessment meeting. All students consented to participate in the study and obtained their parents' or guardians' consent through an Informed Consent Form. This study was approved by the Research Ethics Committee of the Federal University of Rio Grande do Sul under number 19832 and met Resolution 196/96 of the National Health Council.

\section{Instruments}

Two instruments were used-(1) the BackPEI (NOLL et al., 2013a) and (2) theLADy (NOLL et al, 2012; NOLL et al., 2013c) — to assess body posture in the following DLAs: sitting to write and to use the computer, picking up an object off the floor, and carrying a backpack.

The BackPEI is a self-applicable questionnaire with 21 questions that aims to assess the students' body perception when executing the following DLAs: sleeping, sitting in a chair to write in class, sitting in a chair to talk to friends, sitting in a chair to use a desktop computer, picking up an object off the floor, and carrying school supplies. In addition, the instrument asks the respondent about other factors, such as behavioral habits and back pain.

Some BackPEI questions present alternatives, illustrated with pictures, where the respondent must mark the posture that most closely resembles his or hers. Of the pictures presented in these questions, only one represents an appropriate posture for performing the DLAs, and all others are considered inappropriate. This study considered only questions 9 , 11,12 , and 14, all of which had photo illustrations.

The LADy consists of a qualitative analysis of filming during the execution of nine DLAs: (1) posture when seated to write, (2) posture when seated in a chair to use a desktop computer, (3) posture when picking up an object off the floor, (4) posture when carrying a backpack, (5) posture when carrying bags, (6) posture when carrying objects, (7) posture when seated in a chair to use a laptop, (8) posture when sleeping, and (9) posture when seated on a bench. The LADy uses a scoring sheet with predefined criteria to assess postures in each filmed DLA, providing a final numerical score.

In this study, only the videos of postures (1), (2), (3), and (4) were considered. Table 1 presents the four postures analyzed in this study along with the predefined criteria for each DLA (NOLL, 2012; NOLL et al., 2013c). Only postures reaching maximum scores when executing each DLA were rated as adequate. Any posture not reaching a maximum score was rated as inadequate.

Table 1 - Description of postures assessed and the respective DLA assessment criteria as per the filming circuit proposed for the LADy according to NOLL (2012) and NOLL et al. (2013c).

\begin{tabular}{|l|l|c|}
\hline \multicolumn{1}{|c|}{ Postures } & \multicolumn{1}{|c|}{ Assessment Criteria } & Score \\
\hline $\begin{array}{l}\text { (1) Seated to } \\
\text { write }\end{array}$ & $\begin{array}{l}\text { 1 - Head in a neutral position } \\
\text { 2- Torso in an upright position }\end{array}$ & $\begin{array}{c}\text { 1 point for } \\
\text { each }\end{array}$ \\
\hline
\end{tabular}




\begin{tabular}{|c|c|c|}
\hline & $\begin{array}{l}3 \text { - Torso leaning on the backrest } \\
4 \text { - Forearm leaning on the table } \\
5 \text { - Foot sole resting on a base or on the floor } \\
6-90^{\circ}\left( \pm 5^{\circ}\right) \text { hip flexion } \\
7-90^{\circ}\left( \pm 5^{\circ}\right) \text { knee flexion } \\
8 \text { - Lower limbs apart } \\
9 \text { - Shoulders aligned }\end{array}$ & $\begin{array}{c}\text { criterion }=9 \\
\text { points }\end{array}$ \\
\hline $\begin{array}{l}\text { (2) Seated on a } \\
\text { chair to use a } \\
\text { laptop }\end{array}$ & $\begin{array}{l}1 \text { - Head in a neutral position } \\
2 \text { - Torso in an upright position } \\
3 \text { - Torso leaning on the backrest } \\
4 \text { - Forearm leaning on the table } \\
5 \text { - Foot sole resting on a base or on the floor } \\
6-90^{\circ}\left( \pm 5^{\circ}\right) \text { hip flexion } \\
7-90^{\circ}\left( \pm 5^{\circ}\right) \text { knee flexion } \\
8 \text { - Lower limbs apart } \\
9 \text { - Shoulders aligned }\end{array}$ & $\begin{array}{l}1 \text { point for } \\
\text { each } \\
\text { criterion = } 9 \\
\text { points }\end{array}$ \\
\hline $\begin{array}{l}\text { (3) Picking up } \\
\text { an object off the } \\
\text { floor }\end{array}$ & $\begin{array}{l}1 \text { - Torso in an upright position } \\
2 \text { - Object between both feet } \\
3 \text { - Knee flexion }\left(\geq 90^{\circ}\right) \\
4 \text { - Symmetrical lower limbs } \\
5 \text { - Foot sole resting on the floor }\end{array}$ & $\begin{array}{l}1 \text { point for } \\
\text { each } \\
\text { criterion }=5 \\
\text { points }\end{array}$ \\
\hline $\begin{array}{l}\text { (4) Carrying a } \\
\text { backpack }\end{array}$ & $\begin{array}{l}1 \text { - Carrying the backpack with a strap on each shoulder } \\
2 \text { - Torso in an upright position } \\
3 \text { - Head in a neutral position }\end{array}$ & $\begin{array}{l}1 \text { point for } \\
\text { each } \\
\text { criterion }=3 \\
\text { points }\end{array}$ \\
\hline
\end{tabular}

Some of the pre-established criteria for postures and/or body positions obtained from the LADy were not taken into consideration in the data analysis, as these are not criteria from the BackPEI questionnaire to consider a posture as adequate. If these criteria were considered in the same way as the others, the results obtained could reveal an inaccurate association. Table 2 shows the LADycriteria not analyzed in this study.

Table 2 - Predefined LADy criteria excluded from the data analysis in this study

\begin{tabular}{|l|l|}
\hline \multicolumn{1}{|c|}{ Postures } & \multicolumn{1}{|c|}{ Excluded assessment criteria } \\
\hline (1) Seated to write & 8 - Lower limbs apart \\
& 9 - Shoulders aligned \\
\hline \multirow{3}{*}{ (2) Seated on a chair to use a laptop } & 8 - Lower limbs apart \\
& 9 - Shoulders aligned \\
\hline (4) Carrying a backpack & 2 - Torso in an upright position \\
\hline
\end{tabular}

\section{Collection procedures}

The questionnaires were completed individually. The assessor remained in the room 
while the students completed the questionnaire, which took 20 minutes on average, and collected them when every student had finished. After this, one student at a time was forwarded to a specific room in order to perform the activity circuit proposed by the LADy instrument. The LADy activities were filmed by the same assessor responsible for the application of the questionnaires.

The execution of the postures was filmed using a camera placed on a movable tripod, allowing for the recoding of the frontal and sagittal planes, according the directionsfor the LADy instrument. However, in this study, for analysis purposes, postures (1), (2), and (3), contained in Table 1, were analyzed only with the images obtained on the sagittal plane. Posture (4) in Table 1 was analyzed only with images recorded on the frontal plane. This procedure was required to ensure that the information from both assessment instruments was analyzed using the same parameters.

In order to assess posture with the LADy, the respondents were asked to put on light clothes that would facilitate body movements and provide a view of the body segments assessed in this filming. Before performing the circuit, students were asked to perform the tasks as they would normally perform them. Each student completed the circuit individually, and the average time for each assessment was 10 minutes.

Analysis procedures

Data regarding the students' posture using the BackPEI questionnaire were converted into tables using Microsoft Excel 2010.

The data regarding the students' dynamic posture using the LADywere collected by a single assessor. The video images were observed using Windows Live Movie Maker, reducing the video speed and using a slow-motion command to enable a better view of the movements of body segments and facilitating the assessment process.

Data referring to postural habits, both those obtained using the BackPEI and those obtained using the LADy, were analyzed using StatisticalPackage for the Social Sciences (SPSS) 20.0. According to Field (2009), the concordance percentage $(\mathrm{C} \%)$ between the data obtained from both instruments was calculated, given by the percentage of identical responses obtained from the BackPEI and the LADy:

$\%$ Concordance $=$ Observed concordance $N$

where:

$\mathrm{N}=$ Total subjects assessed

Observed Concordance $=$ Total coincident results .

A good level of concordance between instruments means the values obtained are greater than $80 \%$ (FIELD, 2009). In order to confirm these data, Kappa's Coefficient (k) was jointly used. The Kappa values were rated as negligible $(\mathrm{k} \leq 0.2)$, poor $(\mathrm{k}=0.21-0.4)$, moderate $(\mathrm{k}=0.41-0.60)$, substantial $(\mathrm{k}=0.61-0.8)$, and excellent $(\mathrm{k} \geq 0.81)$ (LANDIS; $\mathrm{KOCH}, 1977)$. Additionally, the Chi-squared test $\left(\chi^{2}\right)$ was used to compare the frequencies of the results obtained between the BackPEI and the LADy to check whether there is an association between these results. 


\section{Results}

Tables 3 and 4 present the results obtained with the BackPEI and theLADy, respectively. Table 1 presents every posture assessed using the BackPEI, showing the main feature of each as per the illustration contained on the questionnaire and the number of times each posture was marked (frequency and percentage).

Table 3 - Results obtained with the BackPEI for the following postures: carrying a backpack, picking up an object off the floor, sitting to write or use the computer (frequency and percentage for each posture).

\begin{tabular}{|c|c|c|c|c|c|}
\hline \multirow[t]{2}{*}{ Carrying a backpack } & $\begin{array}{l}\text { Only } \\
\text { one } \\
\text { strap } \\
\mathrm{n}(\%)\end{array}$ & $\begin{array}{c}\text { Adequate } \\
\mathrm{n}(\%)\end{array}$ & $\begin{array}{l}\text { In one } \\
\text { hand } \\
\mathrm{n}(\%)\end{array}$ & $\begin{array}{l}\text { In front } \\
\text { of the } \\
\text { body } \\
\mathrm{n}(\%)\end{array}$ & $\begin{array}{c}\text { Another way/don't } \\
\text { know } \\
\text { n }(\%)\end{array}$ \\
\hline & $\begin{array}{c}14 \\
(24.6)\end{array}$ & $\begin{array}{c}42 \\
(73.7)\end{array}$ & $0(0.0)$ & $0(0.0)$ & $1(1.7)$ \\
\hline \multirow[t]{2}{*}{$\begin{array}{l}\text { Picking up an object off the } \\
\text { floor }\end{array}$} & $\begin{array}{c}\text { Stretche } \\
\text { d knees } \\
\mathrm{n}(\%)\end{array}$ & $\begin{array}{l}\text { One leg } \\
\text { forward } \\
\mathrm{n}(\%)\end{array}$ & $\begin{array}{c}\text { Adequat } \\
\mathrm{e} \\
\mathrm{n}(\%)\end{array}$ & $\begin{array}{c}\text { Flexion } \\
>90 \% \\
\text { of the } \\
\text { knees } \\
\text { and hip } \\
\text { n (\%) }\end{array}$ & $\begin{array}{l}\text { Another way/don't } \\
\text { know } \\
\text { n }(\%)\end{array}$ \\
\hline & $6(10.3)$ & $\begin{array}{c}35 \\
(60.4)\end{array}$ & $2(3.4)$ & $\begin{array}{c}15 \\
(25.9)\end{array}$ & $0(0.0)$ \\
\hline \multirow[t]{2}{*}{ Sitting to write } & $\begin{array}{c}\text { Torso } \\
\text { forward } \\
\mathrm{n}(\%)\end{array}$ & $\begin{array}{l}\text { Adequate } \\
\mathrm{n}(\%)\end{array}$ & $\begin{array}{l}\text { Neglected } \\
\mathrm{n}(\%)\end{array}$ & $\begin{array}{c}\text { Crossed } \\
\text { leg } \\
\mathrm{n}(\%)\end{array}$ & $\begin{array}{c}\text { Another way/don't } \\
\text { know } \\
\text { n }(\%)\end{array}$ \\
\hline & $\begin{array}{c}17 \\
(29.3)\end{array}$ & $5(8.6)$ & $\begin{array}{c}31 \\
(53.5)\end{array}$ & $5(8.6)$ & $0(0.0)$ \\
\hline \multirow[t]{2}{*}{ Using the computer } & $\begin{array}{c}\text { Torso } \\
\text { forward } \\
\mathrm{n}(\%)\end{array}$ & $\begin{array}{c}\text { Adequate } \\
\mathrm{n}(\%)\end{array}$ & $\begin{array}{c}\text { Neglected } \\
\mathrm{n}(\%)\end{array}$ & $\begin{array}{c}\text { Crossed } \\
\text { leg } \\
\mathrm{n}(\%) \\
\end{array}$ & $\begin{array}{c}\text { Another way/don't } \\
\text { know } \\
\text { n }(\%)\end{array}$ \\
\hline & $\begin{array}{c}13 \\
(22.4)\end{array}$ & $\begin{array}{c}10 \\
(17.2)\end{array}$ & $\begin{array}{c}33 \\
(56.9)\end{array}$ & $2(3.5)$ & $0(0.0)$ \\
\hline
\end{tabular}

Table 4 presents the results obtained from the analysis of images of the LADy filming circuit in a descriptive manner (median, range, percentages of minimum and maximum scores).

Table 4- Results obtained with the LADyfor the following postures: carrying a backpack, picking up an object off the floor, sitting to write or use the computer (median, range, percentages of minimum and maximum scores).

\begin{tabular}{ccccc}
\hline Variable & $\begin{array}{c}\text { Score } \\
\text { Median }\end{array}$ & Score Range & $\begin{array}{c}\text { \% minimum } \\
\text { score }\end{array}$ & $\begin{array}{c}\% \text { maximum } \\
\text { score }\end{array}$ \\
\hline Carrying a backpack & 1 & 1 & $22.80 \%$ & $77.20 \%$
\end{tabular}


appropriately $(\mathrm{PMax}=1)$

Picking up an object off the floor appropriately (PMax $=5)$

Sitting to write appropriately (PMax $=7$ )

Sitting to use the computer appropriately (PMax =7)

PMax $=$ Maximum score for each posture

The results of the concordance percentage calculations when comparing both dynamic posture assessment instruments are presented in Table 5. These findings indicate that, in every DLA analyzed, the assessment instruments provide consistent information on the students' body posture.

Table 5- Adequate posture results for each of the postures assessed using boththe BackPEI and the LADy: agreement, Kappa coefficient, and association between the instruments.

\begin{tabular}{|c|c|c|c|c|c|c|}
\hline Variable & BackPEI & LADy & Concordance & Kappa & $\begin{array}{c}\text { Value } \\
\text { Chi-square }\end{array}$ & $\chi^{2 \mathrm{a}}$ \\
\hline $\begin{array}{l}\text { Carrying a backpack } \\
\text { appropriately } \\
(\mathrm{n}=57)\end{array}$ & $73.7 \%$ & $77.2 \%$ & $96.5 \%$ & 0.905 & 47.15 & $\underset{\mathrm{b}}{0.001}$ \\
\hline $\begin{array}{l}\text { Picking up an object } \\
\text { off the floor } \\
\text { appropriately } \\
(\mathrm{n}=58)\end{array}$ & $3.4 \%$ & $1.7 \%$ & $98.3 \%$ & 0.962 & 53.78 & $\underset{\mathrm{b}}{0.001}$ \\
\hline $\begin{array}{l}\text { Sitting to write } \\
\text { appropriately } \\
\quad(\mathrm{n}=58)\end{array}$ & $8.6 \%$ & $1.7 \%$ & $93.1 \%$ & 0.737 & 31.51 & $\underset{\mathrm{b}}{0.001}$ \\
\hline $\begin{array}{l}\text { Sitting to use the } \\
\text { computer appropriately } \\
(\mathrm{n}=58)\end{array}$ & $17.2 \%$ & $1.7 \%$ & $84.5 \%$ & 0.483 & 14.757 & $0.01^{\mathrm{b}}$ \\
\hline
\end{tabular}

The concordance levels found between the BackPEI and the LADy were greater than $80 \%$ (Table 5). The values found through the Kappa coefficient and interpreted according to Landis and Koch (1997) ranged from moderate (0.483 on the DLA corresponding to sitting to use the computer) to excellent ( 0.962 on the DLA corresponding to picking up an object off the floor appropriately). There is also a significant association between both assessment instruments in all DLAs (Table 5).

\section{Discussion}

The results indicate that the BackPEI and LADy assess students' dynamic posture in a similar way; their respective results showed agreement and a significant association in the 
analyzed postures. Considering the inexistence of studies comparing results from body posture assessment instruments and the flexibility that these results provide to the assessor when choosing the instrument to perform the assessment, we can see that these results have a practical and scientific relevance.

Schlademann, Meyer, and Raspe (2008) and Mehta, Thorpe, and Freburger (2002) highlight the questionnaire as a very important assessment instrument due to its easy application and low cost. However, Andreotti and Okuma (1999) state that a questionnairebased assessment cannot verify the incorporation of theoretical knowledge from the individual and the transfer of that knowledge to the execution of the movement, something that is possible when using a circuit filming assessment (SPENCE, JENSEN\& SHEPARD, 1984). It is important to highlight that the questionnaire is extremely dependent upon the respondent's cognitive ability, because it is self-reported, which may result in bias in the assessment results.

On the other hand, an assessment through filming in the school environment depends on a few aspects: physical aspects (space and materials), temporal aspects (collection and analysis time), financial resources (acquisition of necessary materials), human resources (field professionals), and pedagogical projects including the application of these assessments (CANDOTTI, ROHR\& NOLL, 2011). In addition, we need to know the strengths and weaknesses of the filming circuit to be used. Noll, Candotti, and Vieira (2013), in a systematic review analyzing the dynamic assessment instruments available in the scientific environment to date, indicated the same aspects previously mentioned as possible difficulties for the functioning of the assessment and warned about the limitations of this type of instrument, mainly when assessing students.

By analyzing the number of students who marked the alternative presenting the correct execution of the DLA of sitting to use the computer in the BackPEI $(n=10)$, and the number of students who practiced the DLA appropriately in the LADy $(n=1)$, there was a $15.5 \%$ difference in the results presented by both instruments and a Kappa coefficient equal to 0.483 , which is rated as moderate. This discrepancy indicates that the results were overestimated by the BackPEI in relation to the LADy. One of the factors for this difference may be the fact that the questionnaire is dependent upon the individual's body perception, that is, the respondent marks the alternative that most closely resembles the one he or she believes he or she practices. In the filming circuit, however, the assessed individual reproduces the execution of the DLA, and a professional is responsible to study the posture and consider it to be adequate or not using well-defined technical criteria in a specific scoring sheet, which tends to convey the stricter assessment character of this instrument.

Another aspect that can be related to the difference in the results between the instruments on the DLA of sitting to use the computer is the psychological effect that the act of being assessed through filming may have on the student, as many people, mainly children and adolescents such as those assessed in this study, feel shy and embarrassed in suchsituations. Although they are instructed by the assessor to perform the tasks as they would normally perform them, students may have reproduced postures that do not match those practiced in daily life. In fact, this is a limitation that is inherent to this type of assessment instrument.

The DLAs of carrying a backpack and picking up and object off the floor presented the most consistent results, with concordance levels over 95\% and Kappa coefficients rated as excellent. Regarding the DLA of carrying a backpack, these results may be explained by the 
fact that only one criterion (carrying a backpack with a strap on each shoulder) was taken into consideration in the analysis of this posture using the LADy, which increases the chances of the posture being assessed as adequate in relation to the other postures analyzed. On the other hand, the BackPEI presentsfour options for carrying a backpack, and regardless of this, most students $(73.7 \%)$ marked the option portraying a backpack being carried with one strap on each shoulder. In this context, the strong association between the results from the BackPEI and the LADy on the DLA of carrying a backpack occurred because the assessment of each instrument is, in essence, similar. Regarding the DLA of picking up an object off the floor, only one student was assessed differently across both instruments, which also suggests a similarity of the assessment between the instruments on this DLA.

Despite the similar postural results provided by both instruments, it is important to highlight that the BackPEI and the LADy differ methodologically and present limitations and advantages of distinct natures. For example, the BackPEI does not depend on assessment by a professional, as it is based on body perception and its transfer to the questionnaire by the respondent. An assessment performed using the LADy, however, is completely dependent upon the assessor's experience, especially his or her ability to see possible misalignments and inadequate postures in the assessed individual's body. In addition, the LADy is governed by a list of predefined criteria, which does not allow any flexibility in the analysis. Therefore, coupled with the fact that the BackPEI tends to overestimate the results in relation to the LADy, an assessment with the LADy is perceived to be stricter when compared to the BackPEI.

It is important to highlight that the selection of one instrument or the other must be guided by reflecting and observing the context and/or type of research in which the assessment will be performed. However, from a practical point of view, the questionnaire is considered to be an instrument suitable for studies such as epidemiological studies, longitudinal design studies, population-based studies, or studies with large samples. This is because it is a low-cost instrument with a fast and practical application providing results that are similar to those of more complex instruments, such as a qualitative analysis of filming. On the other hand, the filming circuit in the LADy seems to be suitable for situations in which there is a need to assess the different aspects than can affect moving body posture qualitatively and with more depth. Because it requires a competent assessor with experience in identifying body misalignments, the LADy is well suited for the professional practice of Physical Education teachers who act as personal trainers and physical therapists. This is reinforced by the fact that the LADy also requires planning to perform the assessment, such as space and appropriate filming materials, as well as sufficient financial and time resources so that the assessment can be performed and analyzed in an appropriate manner. It is important to highlight that both methods studied in this work aim to assess the general postural aspects of students and that there are no data allowing us to indicate these methods for measuring postural details such as joint angles.

The results found in this study show that there is concordance between a test based in the qualitative analysis of filmed activity and one based on a questionnaire for assessing students' body posture in the following DLAs: sitting to write, sitting to use the computer, picking up an object off the floor, and carrying a backpack. Nevertheless, studies assessing different populations and different postures with the referred instruments must be conducted to extend, or not, the concordance level between the types of assessment, since for now, this concordance is only clear for the student population assessed. 


\title{
QUESTIONÁRIOS E FILMAGENS FORNECEM RESULTADOS SEMELHANTES SOBRE A POSTURA CORPORAL DINÂMICA DE ESCOLARES?
}

\section{Resumo \\ Este estudo teve como objetivo verificar se os instrumentos Back Painand Body Posture Evaluation Instrument (BackPEI) e Lay-out for Assessing Dynamic Posture (LADy), que consistem em questionário e análise qualitativa de filmagem, respectivamente, para avaliar a postura corporal dinâmica, Fornecem informações concordantes nas atividades de sentar para escrever, sentar para utilizar o computador, pegar objeto do solo e transportar mochila. A amostra foi composta por 58 escolares de ambos os sexos (idade $=12,94 \pm 1,22$ anos, massa corporal $=52,34 \pm 12,24$ quilos $\mathrm{e}$ estatura $=1,64 \pm 0,07$ metros), que foram avaliados por ambos os instrumentos. Os instrumentos apresentam níveis similares de concordância $(84,5 \%$ a 98,3\%) e associação significativa $(p<0,05)$ nas atividades de vida diária avaliadas. \\ Palavras-chave: Postura. Estudantes. Avaliação postural qualitativa. Concordância. \\ ¿CUESTIONARIOS Y GRABACIONES PROPORCIONAN RESULTADOS SIMILARES SOBRE LA POSTURA CORPORAL DINÁMICA ESCOLAR?}

\begin{abstract}
Resumen
El estudio tuvo como objetivo comprobar si los instrumentos Back Pain and Body Posture Evaluation Instrument (BackPEI) y Lay-out for Assessing Dynamic Posture(LADy), que se utilizan de cuestionario y análisis cualitativo de grabación, respectivamente, para evaluar la postura corporal dinámica. Proporcionan informaciones similares en actividades tales como sentarse a escribir, sentarse a usar la computadora, recoger objetos del suelo y transportar transpórtela mochila. La muestra fue compuesta de 58 escolares de ambos sexos (edad $=12,94 \pm 1,22$ años, masa corporal $=52,34 \pm 12,24$ kilogramos e la altura $=1,64 \pm 0,07$ metros), que fueron evaluados por ambos instrumentos. Los instrumentos presentan niveles similares de concordancia $(98,3 \%$ al $84,5 \%)$ y asociación significativa $(\mathrm{p}<0,05)$ en las actividades de la vida diaria estudiadas.
\end{abstract}

Palabras Clave: Postura. Estudiantes. Evaluación postural cualitativa. Concordancia.

\section{References}

ANDREOTTI, R. A. OKUMA, S. S. Validação de uma bateria de testes de atividades de vida diária para idosos fisicamente independentes. Revista Paulista de Educação Física, São Paulo, v.13, n. 1, p. 46-66, jan./jun., 1999.

BEJIA, I. et al. Reproducibility of a low back pain questionnaire in Tunisian adolescents. Clinical Rheumatology, v.25, n. 5.p. 715-20, 2006.

CANDOTTI, C. T. et al. Efeitos de um programa de educação postural para crianças e adolescentes após oito meses do seu término. Revista Paulista de Pediatria, São Paulo, v. 29, n. 4 p. 577-583., 2011.

CANDOTTI, C. T. ROHR, J. NOLL, M. A Educação Postural como conteúdo curricular da 
Educação Física no Ensino Fundamental II nas escolas da Cidade de Montenegro/RS. Movimento, Porto Alegre, v. 17, n. 3, p. 57-77, 2011.

CARDON, G. CLERCQ, D. BOURDEAUDHUIJ, I. Effects of back care education in elementary schoolchildren.Acta Pediatrica, v. 89, n. 8, p. 1010-7, aug., 2000.

DETSCH, C. et al. Prevalência de alterações posturais em escolares do ensino médio em uma cidade no Sul do Brasil. RevistaPanamericana de SaludPública, v. 21, n. 4, p. 231-8., 2007.

FIELD, A. Discovering statistics with SPSS.Artmed Editora, 2009.

GAYA, A. et al (orgs.). Ciências do movimento humano: introdução à metodologia da pesquisa.Porto Alegre: Artmed, 2008.

KELLIS, E. EMMANOUILIDOU, M. The effects of age and gender on the weight and use of schoolbags.Pediatric Physical Therapy, v. 22, p. 17-25., 2010.

LANDIS JR; KOCH GG.The measurement of observer agreement for categorical data.Biometrics, v.33, p.159-174, 1977.

MARTÍNEZ-CRESPO, G. et al. Dolor de espalda en adolescentes: prevalencia y factores asociados. Rehabilitación, Madrid, v. 43, n. 2, p. 72-80., 2009.

MEHTA, T. B. THORPE, D. E. FREBURGER, J. K. Development of a Survey to Asses Backpack Use and Neck and Back Pain in Seventh and Eighth Graders. Pediatric Physical Therapy, v. 14, n. 4, p. 171-184., 2002.

MÉNDEZ, F. J. GÓMEZ-CONESA, A. Postural hygiene program to prevent low back pain. Spine,v. 26, n. 11, p. 1280-6., 2001.

NOLL, M. Desenvolvimento de um circuito de avaliação da postura dinâmica das atividades de vida diária de escolares. Dissertação (Mestrado em Ciências do Movimento Humano). Universidade Federal do Rio Grande do Sul (UFRGS), Porto Alegre, 2012.

NOLL, M. et al. Alterações posturais em escolares do ensino fundamental de uma escola de Teutônia/RS. Revista Brasileira de Ciência e Movimento, v.20, n. 2, p. 32-42., 2012a.

NOLL, M. et al. Prevalência de dor nas costas e fatores associados em escolares do ensino fundamental do município de Teutônia, Rio Grande do Sul. Revista Brasileira de Saúde Materno Infantil, Recife, v.12, n. 4, p 1-1m oct./dec., 2012b.

NOLL, M. CANDOTTI, C. T. VIEIRA, A. Escola postural: revisão sistemática dos programas desenvolvidos para escolares no brasil. Movimento, (UFRGS. Impresso), JCR, v. 18, p. 265291., 2012.

NOLL, M. CANDOTTI, C. T. VIEIRA, A. Instrumentos de avaliação da postura dinâmica: aplicabilidade ao ambiente escolar. Revista Fisioterapia em Movimento, v. 26, n. 1, p. 203- 
217, jan./mar., 2013.

NOLL, M. et al. Back Pain and Body Posture Evaluation Instrument (BackPEI): development, content validation and reproducibility. International Journal of Public Healt, v. 58, n. 4, p. 565-72, aug., 2013a.

NOLL, M. et al. Prevalência de hábitos posturais inadequados de escolares do ensino fundamental da cidade de Teutônia: um estudo de base populacional. Revista Brasileira de Ciências do Esporte, v. 35, n. 4., 2013 b.

NOLL, M.; et al. Lay-out for assessing the dynamic posture (LADY): development, validation and reproducibility. In: VIII Congresso Internacional de Educação Física e Motricidade Humana, 2013, Rio Claro. Resumos do VIII Congresso Internacional de Educação Física e Motricidade Humana. Rio Claro: UNESP, 2013. v. 19c.

PAANANEN, M. V. et al. Phychosocial, mechanical, and metabolic factors in adolescents' musculoskeletal pain in multiple locations: a cross-sectional study. Pain, v. 14, p. 395-401., 2010.

PENHA P. J. et al. Qualitative postural analysis among boys and girls of seven to ten years of age.RevistaBrasileira de Fisioterapia, v.12 n. 5, p.386-91., 2008.

ROBERTSON, H. C. LEE, V. C. Effects of back care lessons on sitting and lifting by primary students. Australian Journal Physiotherapy, v.36, n. 4, p. 245-8.,1990.

SANTOS, G. ABBUD, E. ABREU, A. Determination of the size of samples: an introduction for new researchers. RevistaCientífica Symposium, v. 5, P. 59-65., 2007.

SCHLADEMANN, S. MEYER, T. RASPE, H.The test-retest reliability of a questionnaire on the occurrence and severity of back pain in a German population sample.International Journal of Public Health, v. 53. N. 2, p. 96-103., 2008.

SHEHAB, D. K.; JARALLAH, K. F. Nonspecific low-back pain in Kuwaiti children and adolescents: associated factors. Journal of Adolescent Health, v. 36, n. 1, p. 32-5., 2005.

SIIVOLA, S. M. et al. Predictive factors for neck and shoulder pain: a longitudinal study in young adults. Spine (Phila Pa 1976), v.29, p. 1662-9., 2004.

SKOFFER, B. Low back pain in 15- to 16-year-old children in relation to school furniture and carrying of the school bag.Spine (Phila Pa 1976), v. 32, n. 24, p. E713-7., 2007.

SMITH, A. O'SULLIVAN, P. STRAKER, L. Classification of sagittal thoraco-lombro-pelvic alignment of the adolescent spine in standing and its relationship to low back pain. Spine, v. 33, n. 19, p. 2101-17., 2008.

SPENCE, S. M. JENSEN, G. M. SHEPARD, K. F. Comparison of methods of teaching 
children proper lifting techniques. Physical Therapy, v. 64, n. 7, p. 1055-66., 1984.

TREVELYAN, F. C. LEGG, S. J. Back pain in school children - Where to from here? Applied Ergonomics, v. 37, p. 45-54., 2006.

WATSON, K. D. et al. Low back pain in schoolchildren: occurrence and characteristics. Pain, v. 97, n. 1, p. 87-92., 2002.

WOMERSLEY, L. MAY, S. Sitting posture of subjects with postural backache.Journal of Manipulative And Physiological Therapeutics, v. 29, n. 3, p. 213-218., 2006.

Recebido em: 28/06/2014

Revisado em: 10/02/2015

Aprovado em: 03/07/2015

Endereço para correspondência:

matiasnoll@yahoo.com.br

Mateus Kunzler

Universidade Federal do Rio Grande do Sul, Escola de Educação Física.

Rua Felizardo, 750 - Jardim Botânico

90690-200 - Porto Alegre, RS - Brasil 